\title{
Development Prospects of the Mangrove Relic of Foulpointe-East Madagascar
}

\author{
Andriamparany Rakotomavo ${ }^{1}$, Diary Salohy Mandimbinirina ${ }^{1}$, Edmond Roger ${ }^{2}$ \\ ${ }^{1}$ ISSEDD: Higher Institute of Sciences, Environment and Sustainable Development, University of Toamasina, \\ Toamasina, Madagascar \\ ${ }^{2}$ DBEV: Department of Plant Biology, Faculty of Sciences, University of Antananarivo, Antananarivo, Madagascar \\ Email: andri.savaivo@blueline.mg
}

How to cite this paper: Rakotomavo, A. Mandimbinirina, D.S. and Roger, E. (2018) Development Prospects of the Mangrove Relic of Foulpointe-East Madagascar. Journal of Environmental Protection, 9, 859-869.

https://doi.org/10.4236/jep.2018.98053

Received: June 1, 2018

Accepted: July 27, 2018

Published: July 30, 2018

Copyright (C) 2018 by authors and Scientific Research Publishing Inc. This work is licensed under the Creative Commons Attribution International License (CC BY 4.0).

http://creativecommons.org/licenses/by/4.0/

\section{Open Access}

\begin{abstract}
Located about fifty kilometers North of Toamasina (East Madagascar), the Commune of Mahavelona Foulpointe has a mangrove relic of about 2 hectares. Despite the ecological and socio-economic roles played by this ecosystem, it remains so far an orphan site, both in terms of official management and development. The purpose of this article is to take stock of the situation with a view to proposing methods for the sustainable development of this small mangrove via valuation of its natural dynamics. Systematic floristic inventory work was carried out, following a linear ABC transect of $50-100 \mathrm{~m}$, from the sea (zone C) to the rear mangrove (zone A). Five mangrove species exist at Foulpointe: Avicennia marina, Sonneratia alba, Bruguiera gymnorrhiza, Rhizophora mucronata, Lumnitzera racemosa. With anthropogenic harvesting and tourism activities in the area, this ecosystem suffers an annual spatial loss of about 0.14 ha between 2009 and 2016. With a natural regeneration rate of about $966 \%$ the small mangrove has a strong capacity for regeneration. Taking into account the pace of current clearing, it would disappear in 10 - 15 years. The valorization of regenerated young plants, followed by intensive preservation and restoration actions, constitutes a sustainable development path.
\end{abstract}

\section{Keywords}

Mangrove, Management, Natural Regeneration, Foulpointe, East Madagascar

\section{Introduction}

With 4260 ha of mangroves [1], the Malagasy East coast accounts for nearly 2\% of Malagasy mangroves [2]-[8]. Described as small mangroves [8] for the most part, these forests are mainly found at the Ambodivahibe, Irodo and Rigny complex, where $84 \%$ of the mangroves in the East of Madagascar are concentrated 
[1] [9]. About 2 hectares in size, the mangrove relic of Foulpointe, a rural commune located about fifty kilometers north of Toamasina (Figure 1), represents only $0.08 \%$ of the mangroves of the East. Despite its small size, this ecosystem plays important socio-economic and ecological roles as raised by [10]. Indeed, mangroves are still an important ecological niche for the food and financial resources of the riparian population [11] [12]. As small as these, they must be considered in the same way as other development factors [1]. However, the mangrove relic of Foulpointe remains unknown; it is an orphan site in terms of official manager and planning. Its ecological potential is not acknowledged because of the lack of investigation to this end. Thus, this article aims to identify the ecological and development potentials of this small mangrove. The objective is to propose a modality of sustainable management through the valuation of its natural dynamics, by combining restoration and actual involvement of the local population.

\section{Materials and Methods}

Systematic floristic inventory work was carried out in plots of $10 \mathrm{~m} \times 10 \mathrm{~m}$. The objective is to identify the different mangrove species and associated plants present in the surveys, their regenerative capacity and their distribution along a linear transect $\mathrm{ABC}$ (Figure 2) perpendicular to the shore, from the sea (zone $\mathrm{C}$ ) to the back mangrove (zone A), over a distance of $50-100 \mathrm{~m}$. In addition to identifying the vernacular and scientific names of the inventoried plants, the following parameters have been recorded:

- Relative abundance A of each species such as:

$$
A=\frac{100 n}{N}
$$

where:

$\mathrm{A}=$ Relative Abundance in \%

$\mathrm{n}=$ number of individuals of the species in survey

$\mathrm{N}=$ total number of individuals of the species in survey, all species combined

- Regeneration rate $\mathrm{T}$ of each species [13], such as:

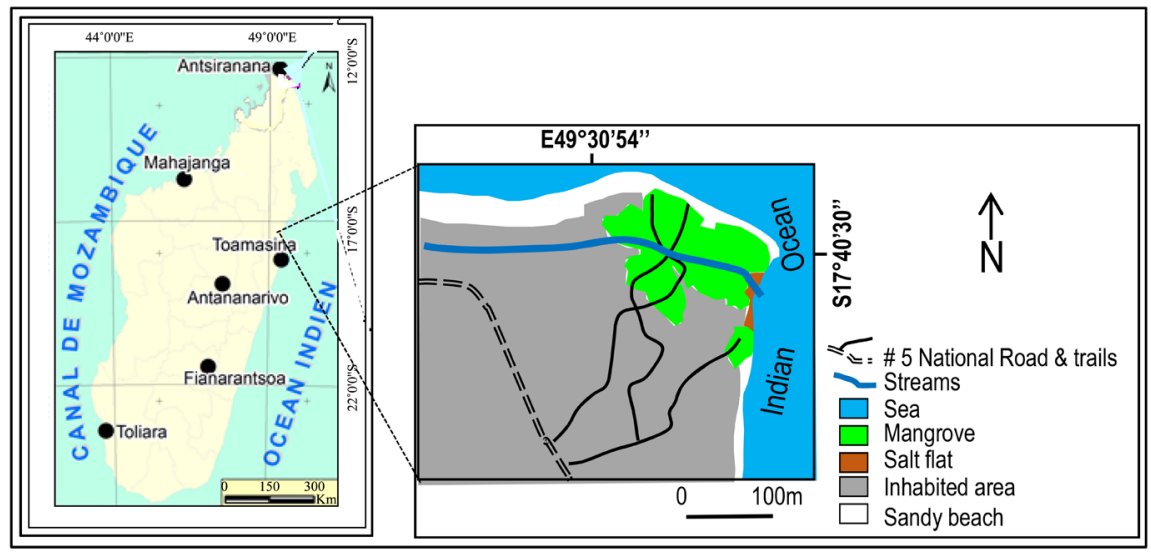

Figure 1. Location of foulpointe mangrove. 


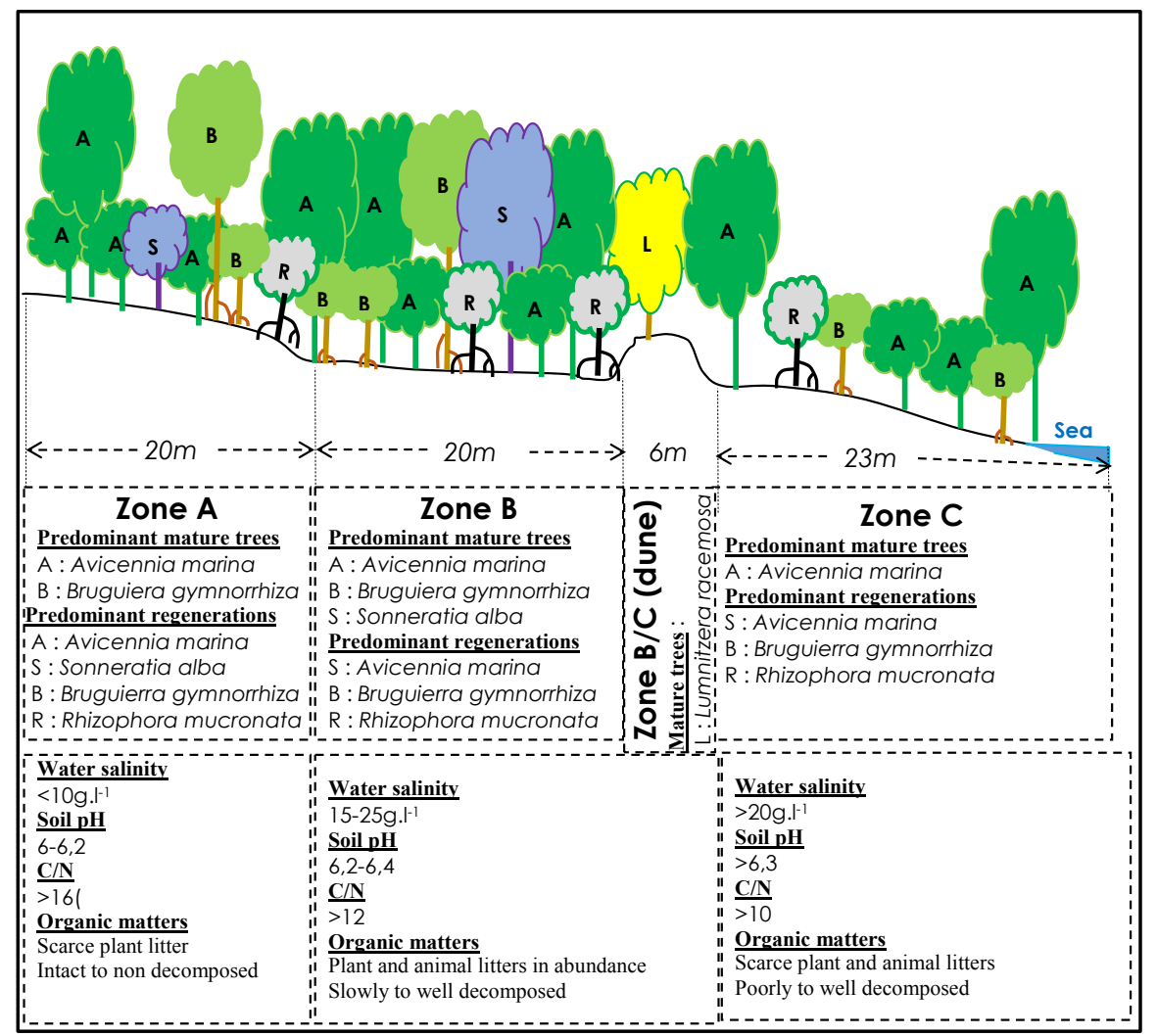

Figure 2. Transect $A B C$ showing the different zoning units, the mangroves encountered and their ecological characteristics.

$$
T=\frac{100 r}{S}
$$

where:

$\mathrm{T}=$ Regeneration rate in $\%$

$\mathrm{r}=$ Number of seedlings less than $1 \mathrm{~m}$ high in the survey

$\mathrm{S}=$ Number of adult seed trees in the survey

with:

if $r>1000 \%$ : very strong regeneration

if $300 \%<r<1000 \%$ : strong regeneration

if $100 \%<\mathrm{r}<300 \%$ : medium regeneration

if $r<100 \%$ : weak regeneration

- Density D of each species, such as $D=100 \mathrm{n}$

where:

$\mathrm{D}=$ Density of the species (individuals $\cdot \mathrm{ha}^{-1}$ )

$\mathrm{n}=$ Number of individuals of the species in a survey of $100 \mathrm{~m}^{2}$

- The $\mathrm{pH}$, the $\mathrm{C} / \mathrm{N}$ ratio and the salinity of the water, which were measured in situ using a handheld multiparameter quality monitoring system horiba u-20 series $u-22.23$.

Factor Correspondence Analysis (FCA), combined with Principal Component Analysis (PCA) identified the plant groups and the stationary conditions in 
which the mangrove is located.

These methods were combined with the diachronic analysis of the 2009 and 2016 satellite images under Geographical Information System. This approach enables to analyze the spatio-temporal evolution of mangrove lots during the period 2009-2016, i.e. during the last seven years. Interviews conducted with potential users of the Foulpointe mangrove, including fishermen, administrative authorities and the local population, allowed to better understand the socio-economic importance of training and the possible local management methods.

\section{Results}

\subsection{Variable Stationary Conditions According to a Zoning}

Salinity of water and soil varies from upstream to downstream, depending on the transect passing through the zones A-B-C (Figure 2). With values between 5 and $10 \mathrm{~g} \cdot \mathrm{l}^{-1}$, it is lower upstream (zone A), to become more and more significant inside the mangrove (zone B: $15-25 \mathrm{~g} \cdot \mathrm{l}^{-1}$ ) and at seafront (zone C: $20-32 \mathrm{~g} \cdot \mathrm{l}^{-1}$ ), depending on the tides and the penetration of seawater to the mainland.

Similarly, the $\mathrm{pH}$ of the water varies significantly from upstream to downstream, with a gradient increasing from 0.1 to 0.2 point. Overall, the channel waters and their soil are acid to neutral $(\mathrm{pH}=6.6$ - 7.2). The soils of Zone A are more acidic than those of shoreline and Zone $\mathrm{B}$, since the process of decomposition of organic matter is slow $(\mathrm{C} / \mathrm{N}>16)$, and the site is drier, less well supplied in animal and plant litter.

\subsection{A Mangrove Relic Dominated by Avicennia marina}

The following 5 mangrove species can be found at Foulpointe: Avicennia marina, Sonneratia alba, Bruguiera gymnorrhiza, Rhizophora mucronata and Lumnitzera racemosa. Figure 3 shows their relative abundance, with a negligible percentage for Lumnitzeraracemosa. First, Avicennia marina predominates everywhere, with an abundance of $87 \%$, followed by Sonneratia alba and Rhizophora mucronata which have a respective abundance rate of $8 \%$ and $3 \%$. Finally, the whole site contains very few individuals of Bruguierra gymnorrhiza, which account for only $2 \%$ of the total number of mangrove stocks recorded.

\subsection{Associated Species Upstream and Downstream}

Other than the few Avicennia marina trees which are 360 individuals. $\mathrm{ha}^{-1}$, the upstream part of the mangrove of Foulpointe is occupied by associated species withstanding ecological conditions relatively identical to those of mangroves. The following species are thus visible in zone A: Phymatodes scolopendria which is a lizard-legged fern, Typhonodorum lindleyanum which is a typical species of eastern Madagascar swamps (species native to Madagascar, Comoros, Mauritius and Zanzibar, according to [14]), Cyperus sp., a species acclimated to wetlands, as well as Terminalia cattapa, a tree native to New Guinea that has naturalized in 


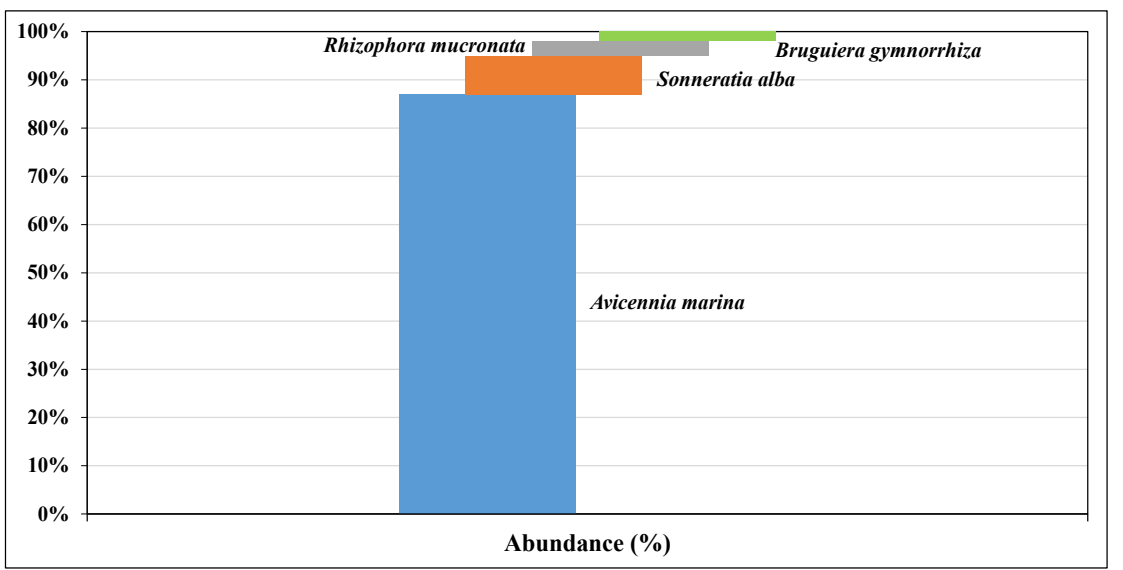

Figure 3. Relative abundance of the 4 main mangrove species encountered at Foulpointe.

several tropical countries [15]. A few Ipomea $s p$ trees are also visible on site, especially at dunes or sandy accumulations. The presence of Citrus $s p$. would show that of the man in and/or around the zone.

Downstream, more precisely in the maritime area $\mathrm{C}$, two species can be distinguished: Terminaliacattapa and Dracaena $s p$. The presence of the latter would also be linked to that of the man, who uses it as a holding pen on the east coast of Madagascar. Moreover, Dracaena sp. acclimates to well-drained wet sites such as stream banks and momentarily flooded places.

Inside the mangrove (zone B) where the trees are more closed, the soil permanently well soaked, the associated species encountered are scarce. The following four mangrove species predominate: Avicennia marina (310 individuals $\left.\cdot \mathrm{h}^{-1}\right)$, Sonneratia alba (20 individuals $\left.\cdot h \mathrm{a}^{-1}\right)$, Bruguiera gymnorrhiza (190 individuals $\cdot \mathrm{ha}^{-1}$ ) and Rhizophora mucronata (140 individuals $\cdot \mathrm{ha}^{-1}$ ).

\subsection{A High Regeneration Capacity}

With a regeneration rate of $3615 \%$, zone $\mathrm{A}$, located at the inner limit, has a high regeneration potential, according to the Rothe scale [13]. The other two zones B and $C$ respectively record high rates of $819 \%$ and $929 \%$. In all, the entire mangrove relic of Foulpointe regenerates well if one refers to its overall regeneration rate of the order of $966 \%$.

\subsection{Cutting Traces Left by Local Residents}

Cuttings of Avicennia marina and Sonneratia alba mature trees are visible, from upstream to downstream, at the level of the 3 zonings. In total, 48 trees $\cdot \mathrm{ha}^{-1}$ were felled by residents in 2016 for construction and service wood. $21 \%$ of harvestings are taken at the inner limit of the mangrove (zone A), while $62 \%$ and $17 \%$ are concentrated respectively inside (zone B) and on the maritime border (zone C).

\subsection{Gateways for Anthropogenic Pressures}

With anthropogenic harvests and tourism activities in the zone, this ecosystem suffers an annual spatial loss of about 0.14 ha between 2009 and 2016, a low for- 
est loss of $0.02 \%$. year ${ }^{-1}$ if one refers to the spatial loss reported by [16] of $1.2 \%$.year $^{-1}$ for all the various types of mangrove cover in Fagnemotse Bay (southwestern Madagascar). According to these authors, 1.8\% of closed canopy mangroves are converted annually into semi-closed cover; between 2002 and $2014,0.8 \%$ of semi-closed canopy mangroves turned into open mangroves each year, while the transition to land formation is only $0.02 \%$. year ${ }^{-1}$ of the latter type of mangrove.

At Foulpointe, Avicennia marina and Sonneratia alba are the most targeted species for cutting because of their size (trunk diameter and height of up to more than $50 \mathrm{~cm}$ and $8 \mathrm{~m}$ respectively). These cuttings are favored by the gateways in terms of anthropogenic pressures hereafter:

- Canoe berthing. Zones C and B, located respectively on the seafront and inside the mangroves, are the subject of moorings for canoe and traditional fishermen. 10 to 65 regenerations of Rhizophora m., Avicennia m. and Bruguiera $g$. are regularly trampled by the site users, whose area could be evaluated between 100 and $200 \mathrm{~m}^{2}$ ( 3 - 5 canoes per day).

- Existence of trails inside the mangrove. Approximately $350 \mathrm{~m}$ long, small openings 0.5 to $1.2 \mathrm{~m}$ wide, including two trails $75 \mathrm{~m}$ north of the north mangrove lot, two others south-west of it, and a small $50 \mathrm{~m}$ trail southwest of the southern lot. These openings are not only subject to regular trampling by mangrove users, but they are also a factor of disturbance, or even destruction of the seedlings along these trails. Access to mangrove lots becomes easier with these openings.

- Fishing for crabs and other invertebrates, which encourages fishermen to penetrate deeper into the mangrove, causing losses in regeneration due to the use of basket traps and the trampling of seedlings by fishermen.

- Open defecation, the practice of which remains current for nearly $10 \%$ of the riparian people surveyed. The dumping of liquid and solid waste, as well as the lack of adequate sanitation infrastructure for urban roads could affect the resilience of Foulpointe mangroves.

\section{Discussions and Development Prospects}

\subsection{Possibility of Maintaining or Even Extending the Current Area}

Taking into account the current pace of clearing, in the lack of a preservation policy and in the event of disruption of the natural regeneration dynamics, the small mangrove of Foulpointe would disappear in the next 10 - 15 years. However, the station conditions of this ecosystem, like the salinity of water and soil, the exposure to tides, as well as the zoning typical of other Malagasy mangroves, would be favorable indicators for the installation, development or even spatial extension of the current relic. The absence of Ceriops tagal in Foulpointe mangrove would indicate the existence of a shadier forest environment after predominance of an association Rhizopora mucronata and Bruguiera gymnorrhiza [1] [17]. Indeed, the inner and intermediate parts of the mangrove (zone B) should 
normally have been a preferred site of Ceriops tagal, given their geographical position [17] [18] [19] [20]. However, the absence of non-compacted sandy-loam soil would be a limiting factor for the species, especially since the presence of $\mathrm{Bu}$ guiera gymnorrhiza (190 individuals.ha ${ }^{-1}$ ) and the predominance of Avicennia marina (310 individuals $\cdot \mathrm{ha}^{-1}$ ) in situ indicate a more compacted soil [17] [18] [19] [20], and a large ecological amplitude site such as [7] [21] [22] [23] [24] [25] have raised it in the case of the mangroves of Vietnam, Besalampy, Mangoky and Tsiribihina (Madagascar). The sudden presence of Lumnitzera racemosa in the zone between B and C indicates a site that is not very affected by the tides (dune elevation, Figure 2), being at the limit of the high tide, although this zone is supposed to locate in full intertidal space. This presence explains the stress experienced by some Rhizophoraceae such as Bruguiera and Rhizohopra, as well as the notable absence of Ceriops. Viewed in this way, the plant succession mechanism in the mangrove of Foulpointe would still be incomplete, as the site cannot find the ideal conditions for the installation of species that are not very tolerant of sand, high salinity and the predominance of species with high ecological amplitude, such as Avicennia marina.

By referring to the theory mentioned, concerning the mangrove density balance of the Mangoky Delta (SW Madagascar), according to which "gains are provided by natural regeneration and stockpiles of individuals in place, while losses are related to human clearing and natural decline of trees" [7], it is appropriate to intervene at the level of the following three factors if we want to develop the Foulpointe forest relic sustainably: promotion of natural regeneration, rational management of the stocks and control of the clearings The balance between the stock, the regeneration process, as well as the anthropogenic harvesting must be monitored in order to maintain the integrity of the ecosystem [1]. Non disturbance of the natural plant succession mechanism is one of the recommended methods to maintain or increase the area of the current relic.

\subsection{Passive Restoration in the Mangrove and Active Restoration on the Mainland}

The valuation of young regenerated plants, followed by intensive preservation and restoration actions, constitutes a sustainable management path for the mangrove of Foulpointe. The restoration activities will have a double facet:

- Passive restoration via recovery of natural regrowth. The non-disruption of regeneration through a strict prohibition of the area would prevent trampling seedlings by users of the site such as fishermen, boatmen and residents (waste liquid and solid waste), defecation in the open, wood harvesting). The gradual invasion of the site by Rhizophoraceae after installation of the pioneer species (Avicennia) will create a forest environment favorable to the development and increase of regeneration [7].

- Reforestation on the periphery, that is to say on the mainland, with native species already present on the spot. As the percentage of use of mangrove 
woods depends on the existence of woody sources other than mangroves [17], the balance could be maintained in favor of mangroves thanks to the existence of wood from the mainland. For the case of Sainte Marie, the presence of Grevillia banksii, Eucalyptus sp. and Melaleuca quinquenervia on the mainland, near the riparian villages of the mangrove lots is one of the preservation factors of the mangroves of the island [26]. Hence the low utilization rate of $3 \%$ of mangrove wood in construction in Sainte Marie, against $66.7 \%$ to $87.5 \%$ in the Tsiribihina delta, in the southwestern part of Madagascar [17].

Here are some accompanying measures to ensure success of a passive restoration:

- Defending the 2 current mangrove lots by officially clarifying the institution(s) in charge of their management. Closing said lots would be one of the possible measures to avoid any ambiguity in the delimitation of the site to be protected. For this, the 2 current lots can be put in a single enclosure in order to extend their current surface and to ensure the spatial continuity of the corridor which connects them.

- Deletion of total or part of the three paths which are currently crossing the two lots; transforming them into suspended bridges that would allow both good water circulation and a guided tour for tourists.

- Promotion of other socio-economic alternatives other than fishing in the mangrove: ecotourism and guiding services around the current mangrove lots , promoting offshore fishing by giving priority support to traditional small-scale fishermen who have exploited these lots.

- Development and implementation of land-use planning tools including mangrove; construction of road infrastructure for good sanitation of liquid and solid waste in Foulpointe agglomeration.

- Implementation of an environmental education policy favoring the mangrove, creating in the area a museum of information and collections of herbaria and animals, which will be visited by residents and tourists. The mangrove of Foulpointe should thus be part of the sites the children have to visit as part of the improvement of the environmental education system in the school districts of the Atsinanana Region [27] [28].

\subsection{Clear Responsibility of the Stakeholders}

Being a popular tourist site in the Atsinanana Region, Foulpointe has a certain number of assets to sustainably preserve its mangrove relic. The existence of a municipality will in this direction was felt during the interviews conducted with the local council leaders. It is therefore clear that the effective involvement of the population and the valuation of the natural regeneration mechanism could be an effective way to preserve and enhance this relic. But the real strategy is to clarify the roles and responsibilities of those in charge of relic management. The table gives an outline of the charter of responsibilities of the stakeholders likely to be 
involved in the sustainable management of the Foulpointe mangrove (Table 1).

\section{Conclusions}

The interest of this study lies in:

- The knowledge of the Foulpointe mangrove forest, which until now remains little known in terms of structures and pressures, two basic details that are essential for its sustainable development and management.

- The "renaturation" of the site through a natural approach favoring regenerations and the natural reconstitution process.

- The safeguarding of a micro-ecosystem which, despite its small spatial extent, requires the effective and clear involvement of a certain number of users and stakeholders. Clarification of the roles and responsibilities of the latter is a key to the successful management of the current forest relic.

- The existence of a number of ecological stress indicators for certain species such as Lumnitzera racemosa and Bruguiera gymnorrhiza. If these species have difficulty settling on site, Ceriops tagal is absent due to unsuitable ecological and anthropogenic conditions, making the plant succession process incomplete.

Table 1. Outline of roles and responsibilities of the stakeholders in the sustainable management of Foulpointe mangrove relic.

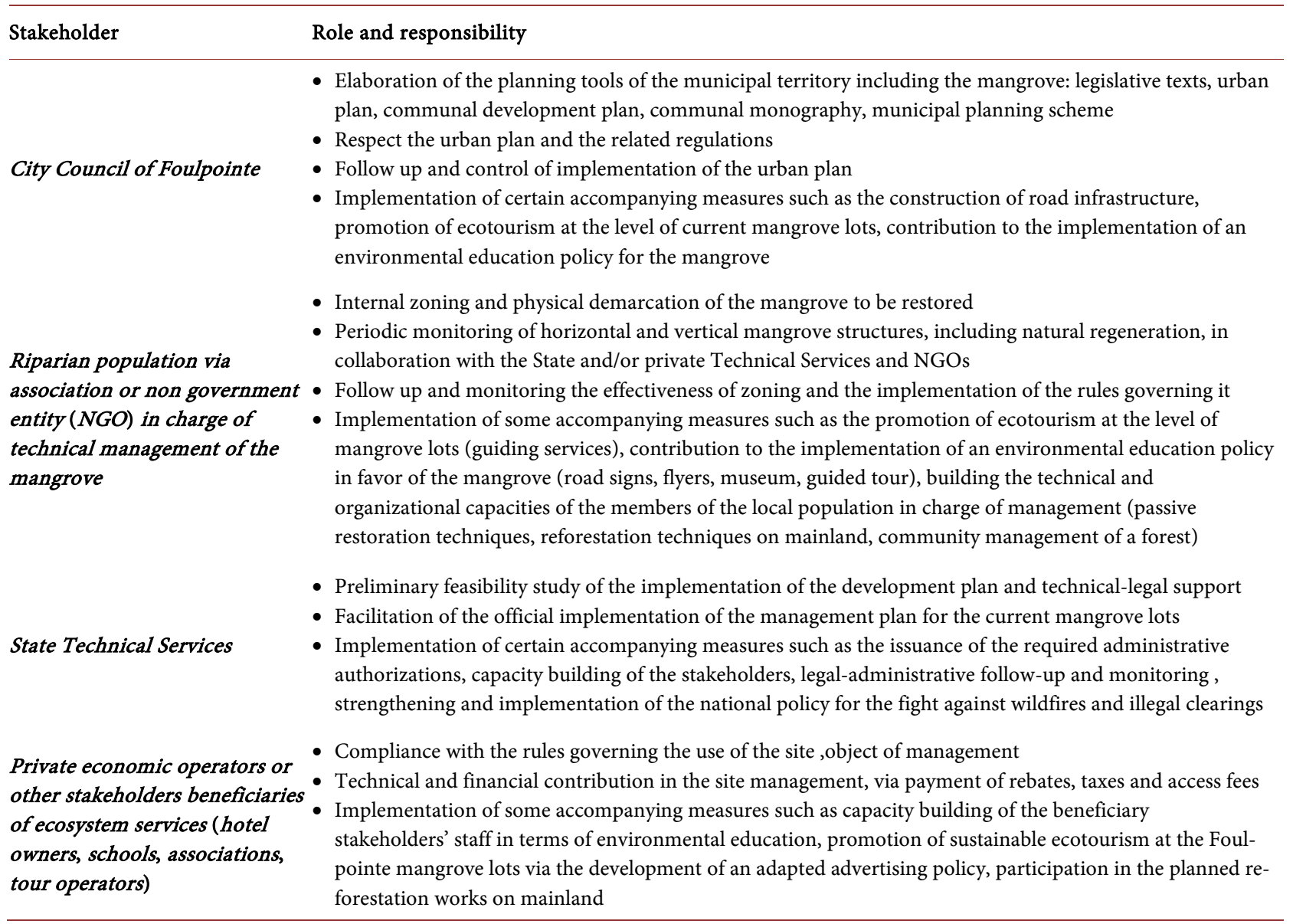


The information provided in this study is a decision-making tool, and an alarm signal on the urgency of the sustainable management of this endangered Eastern small ecosystem. In any case, the site reconstruction should be carried out through a renaturation process.

\section{References}

[1] Rakotomavo, A. (2017) Les mangroves de l'Est malgache: potentiels écologiques et pressions. Actes du Colloque International sur les mangroves des îles de l'Océan Indien occidental: dynamique, pressions, gestions. Mahajanga 18 au 21 septembre 2017. MESUPRES-IRD. (In Prep)

[2] Kiener, A. (1972) Ecologie, biologie et possibilités de mise en valeur des mangroves malgaches. Bulletin de Madagascar, 308, 49-80.

[3] Lebigre, J.M. (1984) Problématiques de recherche sur les marais maritimes de Madagascar en vue de leur protection et leur aménagement. Revue de Géographie, 44, 45-74.

[4] Taylor, M., Ravilious, C. and Green, E.P. (2003) Mangroves of East Africa. UNEP-WCMC Biodiversity Series No. 13, 24 p. https://www.unep-wcmc.org/

[5] Jeannoda, V. and Roger, E. (2008) Honko: introduction générale. Honko $\mathrm{n}^{\circ} 1$. Département de Biologie et Ecologie Végétales, Faculté des Sciences d'Antananarivo, $252 \mathrm{p}$.

[6] Giri, C. and Muhlhausen, J. (2008) Mangrove Forest Distributions and Dynamics in Madagascar (1975-2005). Sensors, 8, 2104-2117. https://doi.org/10.3390/s8042104

[7] Rakotomavo, A. (2010) Etat des lieux et dynamique de la mangrove du delta de Mangoky-sud-ouest de Madagascar. Thèse de doctorat ès Sciences Agronomiques, Université d'Antananarivo, $151 \mathrm{p}$.

[8] WWF (2007) Etat des lieux des mangroves face au changement climatique à Madagascar. $30 \mathrm{p}$.

[9] Rakotomavo, A., Rasoamanarivo, R.M.M, Andrianoelisoa, R.H., Razafimamonjy F., Razafinarivo, O.H., Razanajaza, P., Rafilipo, L.A., Betsiafindra, J.M., Maro, C.A, Ralaizandriarison, J.C, Randriamiarina, R.V., Sangotra, A.D., Randrianarisoa, A.H and Rakotoson, M.F. (2017) Carte d'identité des mangroves de l'Est malgache. Actes du Colloque International sur les mangroves des îles de l'Océan Indien occidental: dynamique, pressions, gestions. Mahajanga 18 au 21 septembre 2017. MESUPRES. (In Prep)

[10] Mumby, P.J., Edwards, A.J., Arias-Gonzalez, J.E., Lindeman, K.C., Blackwell, P.G., Gall, A., Gorczynska, M.I., Harborne, A.R., Pescod, C.L., Renken, H., Wabnitz, C.C. and Llewellyn, G. (2004) Mangroves Enhance the Biomass of Coral Reef Fish Communities in the Caribbean. Nature, 427, 533-536.

https://doi.org/10.1038/nature02286

[11] Mandimbinirina, D.S. (2017) Caractérisations ethnoécologiques de la petite mangrove de la Commune rurale Mahavelona Foulpointe, une zone humide à potentiel élevé mais sans gestionnaire. Mémoire de Master II en Sciences, Environnement et Développement Durable, ISSEDD-Université de Toamasina, Toamasina, $78 \mathrm{p}$.

[12] Andriamalala, C.A.J. (2007) Etude écologique pour la gestion des mangroves à Madagascar: Comparaison d'une mangrove de littorale et d'estuaire à l'aide de la télédétection. Thèse de Doctorat, Univeresité de Basel, Basel, 268 p.

[13] Rothe, P.L. (1964) Régénération naturelle en forêt tropicale: Le Dipterocarpusdyeri (Dau) sur le versant cambodgien du golfe du Siam. Bois et Forêt des Tropiques, 8, 
386-397.

[14] Demi, B. (2000) Aroids: Plants of the Arum Family. Timber Press, Portland, OR.

[15] Fournet, J. (2002) Flore illustrée des phanérogames de Guadeloupe et de Martinique. CIRAD Editions, Gondwana.

[16] Benson, L., Glass, L., Jones, T.G., Ravaoarinorotsihoarana, L. and Rakotomahazo, C. (2017) Mangrove Carbon Stocks and Ecosystem Cover Dynamics in Southwest Madagascar and the Implications for Local Management. Forests, 8, 190. https://doi.org/10.3390/f8060190

[17] Razakanirina, H. (2016) Les mangroves de Madagascar: Utilisation des ressources en bois, caractéristiques anatomiques du bois et vulnérabilité écologique par rapport au changement climatique (Cas des mangroves du delta de Tsiribihina et de la Réserve de Biosphère de Sahamalaza). Thèse de doctorat en Sciences de la vie et de l'Environnement-Sciences du végétal, Université d'Antananarivo, Antananarivo, $177 \mathrm{p}$.

[18] Tostain, S. (2010) Les espèces de palétuviers dans les mangroves de Tuléar. Formad Environnement, $32 \mathrm{p}$.

[19] Kathiresan, K. and Bingham, B.L. (2001) Biology of Mangroves and Mangrove Ecosystems. Advances in Marine Biology, 40, 81-251. https://doi.org/10.1016/S0065-2881(01)40003-4

[20] Kathiresan, K., Rajendran, N. and Thangadurai, G. (1996) Growth of Mangrove Seedlings in Intertidal Area of Vellar Estuary Southeast Coast of India. Indian Journal of Marine Sciences, 25, 240-243.

[21] Rakotomavo, A. and Fromard, F. (2010) Dynamics of Mangrove Forests in the Mangoky River Delta, Madagascar, under the Influence of Natural and Human Factors. Forest Ecology and Management, 259, 1161-1169.

[22] Randriamboavonjy, J.C. and Rakotomavo, A. (2012) Les sols du delta de Mangoky (Sud-Ouest malgache): Leurs caractéristiques Physico-Chimiques sous différents faciès de mangrove. Madamines, 4, 62-77.

[23] Hong, P.N. and San, H.T. (1993) Mangroves of Vietnam. IUCN Wetlands Programme, Gland, Switzerland, $173 \mathrm{p}$.

[24] Andriamasinoro, S.M. (1993) Mobilité: Réponses des sociétés paysannes face à l'instabilité des conditions naturelles d'un milieu deltaïque. Exemples de quelques villages du delta de la Tsiribihina, centre ouest de Madagascar. Mémoire de l'Ecole Normale Supérieure de l'Université d'Antananarivo, Antananarivo, 92 p.

[25] Ratsimba, L.H. (1993) Stratégies paysannes de l'utilisation d'un milieu deltaïque: Exemple de Kaday, delta de la Tsiribihina-Centre Ouest de Madagascar. Mémoire pour l'obtention du CAPEN, Ecole Normale Supérieure de l'Université d'Antananarivo, Antananarivo, $115 \mathrm{p}$.

[26] Rasoamanarivo (2017) La mangrove de Sainte Marie, un écosystème aux enjeux multiples. Mémoire de Master, Faculté des Lettres et Sciences Humaines, Mention Géographie, Université d'Antananarivo, Antananarivo, 65 p.

[27] Andrilalo, F.D. (2017) Analyse critique des programmes d'éducation environnementale dans la Circonscription Scolaire (CISCO) de Toamasina I. Mémoire pour l'obtention du diplôme d'Étude Approfondies (DEA). ISSEDD-Université de Toamasina, Toamasina, $77 \mathrm{p}$.

[28] Marie, S. (2017) La Réserve Spéciale d'Analalava (Commune Rurale de Mahavelona Fouslpointe, District de Toamasina II, Région Atsinanana), un site pédagogique modèle en matière d'éducation environnementale. Mémoire de Licence, ISSESDD-Université de Toamasina, Toamasina, 30 p. 